\title{
Kajian Pelaksanaan Program Insiminasi Buatan dalam Mendukung Program Pencapain Sejuta Ekor Sapi Pemerintah Sulawesi Selatan
}

\author{
Rahmawati Sultan \\ Program Studi Peternakan Fakultas Ilmu Pertanian Universitas Al Asyariah Mandar \\ rahmayoelia@gmail.com
}

\begin{abstract}
Abstrak
Penelitian ini bertujuan untuk mengetahui perkembangan populasi sapi, tingkat kelahiran dan hasil pelaksanaan Inseminasi Buatan di Sulawesi Selatan dan sejauh mana optimalisasi pelaksanaan IB di Sulawesi Selatan dalam mendukung program pemerintah Gerakan Pencapaian Populasi Sapi Sejuta Ekor (GPPSS) tahun 2013. Penelitian dilaksanakan mulai bulan Mei 2010 di kabupaten Bantaeng, Bulukumba, Soppeng, Barru, Sidrap, dan Pinrang dengan mengumpulkan data primer dan sekunder yang diperoleh berdasarkan jenis data kualitatif dan data kuantitatif. Hasil penelitian menunjukkan bahwa trend kelahiran hasil IB dan kawin alam dari ke 6 (enam) kabupaten pada tahun 2006 sampai dengan tahun 2009 rata-rata mencapai 38,89\%. Dari acuan tersebut didapatkan asumsi jumlah populasi total pada tahun 2013 ditaksir sebanyak 843.225 ekor sedangkan untuk trend kelahiran hasil IB saja didapatkan dari ke 6 (enam) kabupaten pada tahun 2006 sampai dengan tahun 2009 rata-rata mencapai 38,36\% dengan asumsi untuk jumlah populasi total pada tahun 2013 untuk kelahiran IB sebanyak 811.318 ekor. Jika diasumsikan trend kelahiran $50 \%$ berdasarkan tingkat kelahiran di negara lain, maka didapatkan jumlah populasi akan mencapai 995.894 ekor, sedangkan prediksi GPPSS 2013 mencapai 1.0167 .29 ekor sapi. Penelitian ini dapat disimpulkan bahwa populasi ternak sapi Propinsi Sulawesi Selatan menunjukkan peningkatan dari tahun 2006 yaitu 637.128 ekor menjadi 703.965 pada tahun 2009, dan populasi hasil IB di setiap kabupaten cenderung mengalami peningkatan setiap tahunnya meskipun pertambahannya relatif sedikit sehingga dapat diprediksi bahwa jumlah kelahiran hasil IB tidak dapat mendukung program pemerintah GPPSS 2013 dengan demikian target pemerintah Propinsi Sulawesi Selatan mengenai program sejuta ekor sapi tidak dapat tercapai jika trend kelahiran tetap pada nilai 38,8\% sampai tahun 2013.
\end{abstract}

Keywords : IB, GPPS, Sapi.

\section{Pendahuluan}

Pembangunan subsektor peternakan adalah bagian integral dari pembangunan pertanian secara menyeluruh, untuk mewujudkan kondisi peternakan yang maju, efisien dan tangguh, dengan bercirikan : mampu meningkatkan pengetahuan, keterampilan dan sikap sumber daya manusia peternakan; mampu memenuhi kebutuhan masyarakat; mampu menyesuaikan pola produksi sesuai permintaan pasar (pola agribisnis); mampu menyumbang pembangunan daerah, menyerap tenaga kerja serta mampu memperbaiki taraf hidup/pendapatan petani/peternak.

Bahwa sub sektor peternakan telah memberikan kontribusi dalam pembangunan pertanian, maka diharapkan dimasa kini dan mendatang akan menjadi salah satu bagian dari pertumbuhan ekonomi baru, yang semula dititikberatkan kegiatannya pada budidaya ternak, cakupannya harus diperluas menjadi "industri biologis" yang dikendalikan oleh manusia dengan empat aspeknya yaitu : Peternak sebagai subyek harus ditingkatkan pengetahuan, keterampilan dan sikapnya menuju peningkatan pendapatan dan kesejahteraannya. Ternak sebagai obyek harus ditingkatkan produksi dan produktifitasnya. Lahan serta lingkungan sebagai basis ekologi dan ekosistem harus dimanfaatkan secara optimal seimbang dan dijaga kelestariannya. Teknologi sebagai alat untuk mencapai tujuan yang diharapkan.

Faktor penghambat yang diduga sebagai penyebab rendahnya produktivitas ternak di Indonesia adalah manajemen pemeliharaan yang belum optimal, yang ditandai dengan sistem pemeliharaan bersifat ekstensif (tradisional), usaha sambilan (non agribusiness oriented) dan tidak memperhatikan input produksi. Selain itu, sistem pemuliaan dan seleksi yang tidak terarah sehingga mengakibatkan kinerja ternak sangat beragam. Selain itu populasi ternak sapi di Sulawesi Selatan semakin rendah dan tingkat kelahiran semakin menurun.

Untuk mengatasi permasalahan tersebut perlu dilakukan suatu terobosan melalui penerapan bioteknologi dalam bidang reproduksi ternak, seperti bioteknologi inseminasi buatan (IB) sebagai salah satu bioteknologi reproduksi yang telah digunakan dalam pembinaan produksi peternakan, khususnya dalam upaya peningkatan produksi dan perbaikan mutu genetik ternak serta sebagai alat dalam pelaksanaan kebijakan pemuliaan secara nasional.

Saat ini Program Percepatan Swasembada Daging Sapi (P2SDS) 2014 merupakan salah satu program dari 21 program utama Departemen Pertanian terkait dengan upaya mewujudkan ketahanan pangan hewani asal ternak berbasis sumberdaya domestik. Program ini juga merupakan peluang untuk dijadikan pendorong dalam mengembalikan Indonesia sebagai eksportir sapi seperti masa lalu. Departemen Pertanian juga menjalin kerja sama di bidang pengembangan teknologi dengan beberapa perguruan tinggi. Ada 20 propinsi yang sementara ini menjadi prioritas dalam program swasembada ini, yakni propinsi-propinsi yang 
terletak di Pulau Jawa, Sumatera dan Bali. Selain itu ada beberapa daerah di Kalimantan, Nusa Tenggara dan Sulawesi.

Sulawesi Selatan sebagai daerah potensial pengembangan sapi pun telah mencanangkan Gerakan Pencapaian Populasi Sapi Sejuta Ekor (GPPSS) pada tahun 2013. Program ini bertujuan mengembalikan kejayaan persapian di Sulawesi Selatan dengan target sejuta ekor sapi tahun 2013 yang diikuti dengan peningkatan kualitas sapi, peningkatan kualitas sumberdaya dan manajemen pemeliharaan. Upaya yang dilakukan pemerintah Propinsi Sulawesi Selatan adalah dengan pencanangan program Gerakan Pencapaian Populasi Sapi Sejuta Ekor (GPPSS) pada tahun 2013, dan salag $\mathrm{h}$ satu bagian dari program ini adalah dengan intensifikasi IB (IB Mandiri) dan kawin alam.

Faktor lain yang menentukan program peningkatan populasi sapi adalah tingkat kelahiran, baik hasil kawin alam maupun hasil kawin suntik/IB (Inseminasi Buatan). Populasi ternak bisa bertambah jika ada kelahiran dan pemasukan ternak. Sebaliknya, menurun jika terjadi kematian, pemotongan dan pengeluaran ternak. Faktor utama yang diperkirakan sebagai penyebab utama menurunnya populasi di daerah ini adalah tingkat kelahiran yang rendah. Hal ini bisa dilihat pada berbagai indikasi. 1)Tingkat pemotongan yang hanya sekitar $10 \%$ dari populasi. Karena aturan yang dipotong hanya anak jantan dan betina tidak produktif, maka angka kelahiran hanya 20-30 \%. 2)Laporan dari berbagai hasil survey dan penelitian. Jarak kelahiran sapi di Sulsel 2-3 tahun, maka angka kelahiran 30-50 \% (Toleng, 2009). Sekitar 500 ekor sapi yang di IB antara tahun 1995-1999, angka konsepsi kurang dari $30 \%$. IB sapi dara dan induk menunjukkan angka kebuntingan 10-20\%. Dari laporan-laporan ini terungkap bahwa rendahnya angka kelahiran berkaitan dengan berbagai faktor antara lain; berahi tanpa ovulasi, kondisi tubuh rendah dan kesalahan manajemen (kegagalan mendeteksi berahi dan kegagalan mengawinkan sapi yang berahi). Mengatasi kendalakendala ini dapat meningkatkan angka kebuntingan menjadi 70-80\% (Toleng, 2009).

Berdasarkan sasaran Rencana Strategis Pembangunan Peternakan 2003 - 2007 yang berhubungan dengan peningkatan populasi ternak adalah terjadi peningkatan rasio jumlah inseminasi per kebuntingan (Services per conception $(\mathrm{S} / \mathrm{C})$ ) dari 2 menjadi 1,5 dan tingkat kebuntingan (Conception Rate) dari $50 \%$ menjadi $70 \%$, namun sasaran ini belum bisa dicapai. Dari dua puluh tiga kabupaten, terdapat 7 kabupaten yang kurang melaksanakan program IB (Selayar, Jeneponto, Soppeng, Wajo, Pangkep, Palopo, Makassar) dan kabupaten Pinrang dan Pare-Pare memperlihatkan kinerja IB yang sangat rendah. Hal-hal di atas akan berdampak kepada tingkat kelahiran hasil program inseminasi buatan (IB) sangat rendah bila dibanding dengan potensi jumlah populasi betina akseptor dan laju penurunan populasi akan tinggi (Sonjaya, 2009).

Agrovital | Jurnal Ilmu Pertanian Universitas Al Asyariah

\section{Metodologi}

Penelitian ini dilaksanakan mulai bulan Mei 2010 di kabupaten Bantaeng, Bulukumba, Soppeng, Barru, Sidrap, dan Pinrang. Berdasarkan kriteria tingkat pengembangan IB yang berbeda-beda dari tiap kabupaten.

Untuk mengukur keberhasilan IB yang berkaitan dengan data populasi sapi mengenai tingkat kelahiran, pemotongan, kematian, pemasukan ternak, persentase akseptor, produksi ternak sapi dan daerah sentra penghasil sapi IB di Sulawesi Selatan, realisasi pelaksanaan IB di daerah, perkembangan IB, efektifitas bantuan pemerintah untuk IB, jumlah akseptor, dan inseminator, pemeliharaan dan manajemen ternak, dan lain-lain, maka data yang dikumpulkan pada penelitian ini adalah data primer dan sekunder yang diperoleh berdasarkan jenis data sebagai berikut :

1. Data kualitatif, dengan wawancara intensif (indepth interview) dengan pejabat yang menangani persoalan terkait, seperti Kabid Produksi dan Pengembangan Ternak Dinas Peternakan Propinsi Sulawesi Selatan, Dinas Peternakan Kabupaten Sidrap, Bantaeng, Bulukumba, Barru, Pinrang dan Enrekang, Badan Pusat Statistik, serta dari inseminator dan peternak/kelompok tani di lapangan di masing-masing daerah, melalui serangkaian pokok-pokok permasalahan yang sudah disiapkan. Misalnya kualitas sperma, tingkat keterampilan inseminator (pendidikan dan pelatihan, jam kerja), respon peternak terhadap IB, kebijakan Pemda (dana operasional IB, RAPBD), dan lain-lain.

2.Data kuantitatif, yang diperoleh berdasarkan survei data-data teknis yang berhubungan dengan program pencapaian sejuta ekor sapi dalam hal ini pelaksanaan inseminasi buatan dan melakukan pengamatan secara langsung terhadap proses penyelenggaraan kegiatan pada obyek penelitian dan dari dinas terkait.

Untuk menguji penelitian ini digunakan analisis deskriptif terhadap jumlah populasi ternak sapi di Sulawesi Selatan sejak satu tahun sebelum pencanangan program GPPSS 2013 dengan menganalisa perkembangan populasi sapi setiap tahunnya dari setiap kabupaten sejak tahun 2006 sampai tahun terakhir ini.

\section{Hasil dan Pembahasan}

\section{Tingkat Kelahiran pada 6 (enam) Kabupaten Penelitian}

Hasil analisa Trend kelahiran IB dan Kawin Alam dari tahun 2006 - 2009 di Sulawesi Selatan pada 6 kabupaten dapat dilihat pada Gambar 1. Berdasarkan grafik dapat dilihat Kabupaten Bantaeng dan Bulukumba menunjukkan perkembangan signifikan dari tahun 2007 sampai dengan 2008 yaitu dengan tingkat angka trend kelahiran pada kabupaten Bantaeng 26,24\% pada tahun 2009 terjadi pertambahan yang sangat tinggi hingga mencapai 73,97 \% trend kelahiran. Demikian juga pada kabupaten Bulukumba dimana pada tahun 2007 nilai trend kelahiran tahun 2009 yaitu 66,73 \%. Untuk kabupaten Sidrap cenderung mengalami penurunan setiap tahunnya dengan nilai trend $3,87 \%$ pada akhir tahun 2009. 


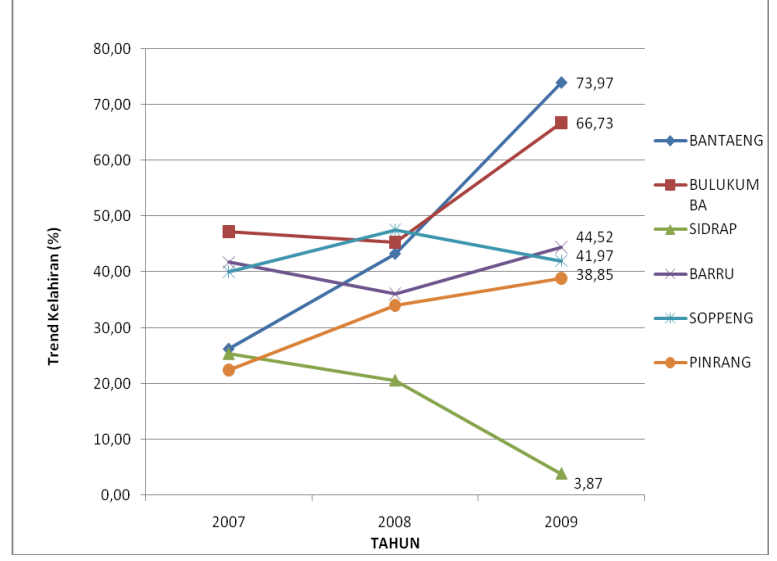

Gambar 1. Grafik Trend Kelahiran di 6 Kabupaten Tahun 2006-2009

Dari hasil analisa tersebut dapat memberi gambaran bahwa upaya penanganan reproduksi ternak sapi yang diusahakan di kabupaten Bantaeng dan Bulukumba umumnya sudah mengarah pada perbaikan mutu. Walaupun sifat usaha peternakan sapi belum mengarah pada pembibitan namun terbatas pada pemeliharaan induk untuk mendapatkan anak dalam kurun waktu tertentu sehingga kemampuan produksi dari ternaknya belum terukur secara kualitas. Adapun penurunan trend kelahiran di kabupaten Sidrap diakibatkan beralihnya minat beternak sapi ke ternak ayam, mengingat sistem pemeliharaannya terbilang mudah dan lebih menjanjikan ditambah lagi meningkatnya kasus pencurian sapi, sehingga motivasi untuk beternak sapi semakin berkurang, serta jumlah pemotongan yang tinggi dan pengeluaran yang meningkat khususnya di tahun 2009.

Berdasarkan survei lapangan dengan 60 responden dari 6 kabupaten menunjukkan bahwa peternak lebih cenderung menjadikan beternak sapi sebagai usaha sambilan dibandingkan usaha pokok, yang pada mulanya memiliki pengalaman beternak lebih lama yaitu diatas 10-20 tahun. Hal ini umumnya diakibatkan karena bergesernya lahan pertanian untuk penggembalaan menjadi bangunan dan industri sehingga sistem pemeliharaan pun berubah yang dulunya digembalakan menjadi ditambatkan atau diberi kandang khusus.

Akibatnya usaha beternak pun beralih ke usaha lain yang lebih memungkinkan peternak memiliki pendapatan yang lebih tanpa menggunakan lahan yang luas untuk memelihara ternaknya. Sejalan dengan itu Putu dkk (1997), menyatakan bahwa faktor-faktor yang perlu diperhatikan dalam melaksanakan perkembangan sapi potong adalah sumber daya yang tersedia seperti sumberdaya alam, sumber daya manusia dan sumber daya pakan ternak yang berkesinambungan, selanjutnya proses budidaya perlu mendapat perhatian meliputi bibit, ekologi dan teknologi serta lingkungan yang strategis yang secara langsung maupun tidak langsung mempengaruhi keberhasilan pengembangannya

Agrovital | Jurnal Ilmu Pertanian Universitas Al Asyariah
Dinyatakan pula oleh Anonim (1999), bahwa jumlah rumah tangga peternak sapi potong hingga tahun 1993 hanya sekitar 1,2\% dari penduduk Indonesia atau sekitar 2.566.000 peternak. Jika masyarakat diberdayakan maka potensi sumber daya manusia sangatlah besar.

Namun demikian Keman (1986) menyatakan bahwa produktivitas sapi daging dapat ditingkatkan baik melalui modifikasi lingkungan atau mengubah mutu genetiknya dan dalam praktek adalah kombinasi antara kedua alternatif diatas. Astuti (1999) menyatakan bahwa beberapa hal yang menyebabkan perkembangan populasi yang lambat adalah rendahnya produktivitas ternak lokal dan masih tingginya mortalitas.

Melihat potensi yang ada di keempat kabupaten terendah tersebut menunjukkan bahwa sistem pemeliharaan yang berlaku tidak diimbangi oleh sistem pengelolaan pakan yang masih bertahan dengan sifat tradisional dimana peternak mencari rumput, membawanya ke kandang kemudian diberikan pada ternak untuk dikonsumsi oleh ternaknya.

Namun upaya lain untuk mendukung sistem pengelolaan pakan seperti menanam hijauan pakan ternak atau pemanfaatan limbah pertanian belum dilaksanakan sehingga pada musim kemarau panjang sapi menjadi kurus, tingkat mortalitas tinggi dan angka kelahiran rendah sebagaimana dinyatakan oleh Subandi dan Zubachtirodin (2004), bahwa dalam meningkatkan produksi ternak sapi, penyediaan pakan dalam jumlah cukup dan kualitas yang memadai harus mendapat perhatian yang besar. Dalam penyediaan hijauan pakan, selain rumput, peranan hijauan yang berasal dari tanaman budidaya, baik itu sebagai hasil samping (limbah) atau produk utama pertanian adalah cukup penting.

Pola pemeliharaan sapi secara intensif banyak dilakukan petani peternak di Jawa, Madura, dan Bali. Pada pemeliharaan ekstensif, ternak dipelihara di padang penggembalaan dengan pola pertanian menetap atau di hutan. Pola tersebut banyak dilakukan peternak di Nusa Tenggara Timur, Kalimantan, dan Sulawesi (Sugeng 2002). Dari kedua cara pemeliharaan tersebut, sebagian besar merupakan usaha rakyat dengan ciri skala usaha rumah tangga dan kepemilikan ternak sedikit, menggunakan teknologi sederhana, bersifat padat karya, dan berbasis azas organisasi kekeluargaan (Yusdja dan Ilham 2004).

\section{Analisis Pencapaian IB di 6 (enam) Kabupaten}

Nilai trend kelahiran yang didapatkan dari ke-6 (enam) kabupaten juga dipengaruhi dari Realisasi Pelaksanaan IB dari tahun 2006 - 2009. Tingkat pencapaian IB dapat dilihat pada Gambar 2.

Data Realisasi Pelaksanaan IB pada tahun 2006 sampai dengan 2009 diperoleh dari masing-masing kabupaten menunjukkan rata-rata persentase IB yang fluktuatif. Kabupaten Bantaeng, Bulukumba Barru, Soppeng, dan Pinrang mengalami peningkatan setiap tahunnya, meskipun pertambahannya relatif sedikit, dan kabupaten Sidrap juga kembali mengalami kenaikan setelah mengalami penurunan di tahun 2007. 


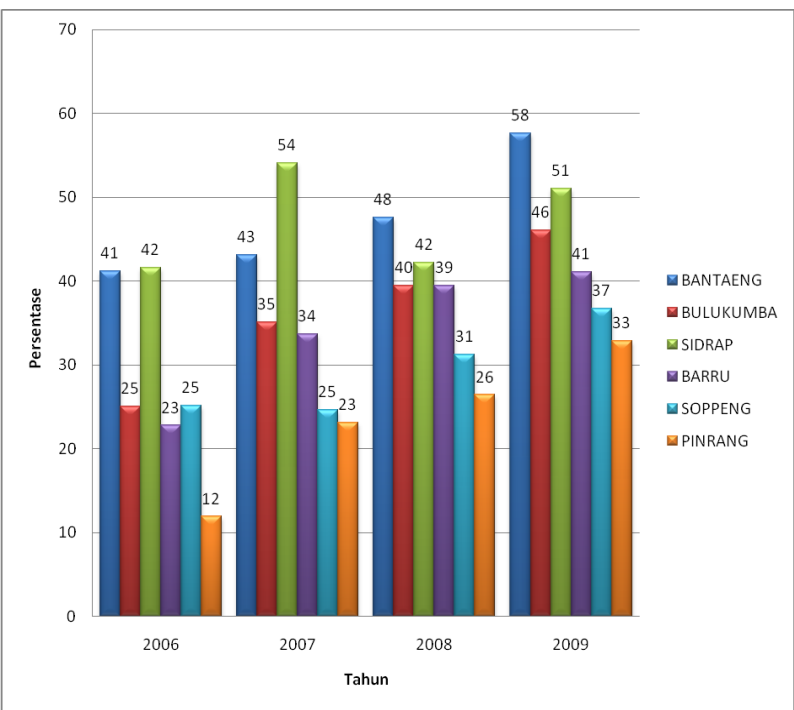

Gambar 2. Grafik Persentase Pelaksanaan IB di 6 Kabupaten Tahun 2006 - 2009

Adapun persentase kelahiran IB tersebut adalah berdasarkan hasil kelahiran dari jumlah akseptor yang berhasil direalisasikan (IB) yang berbeda pula setiap tahunnya di tiap kabupaten. Dengan total persentase mencapai 36,38 \% kelahiran dari total akseptor yang terealisasi akhir tahun 2009 sebanyak 44.968 ekor.

Dengan melihat keberhasilan IB yang fluktuatif, dapat diketahui bahwa manajemen pelaksanaan IB di kabupaten juga beragam. Hal ini terkait pada faktor ternak, peternak, dan petugas inseminatornya di wilayah tersebut. Sehubungan dengan penelitian ini dari 6 kabupaten dengan responden 60 inseminator dan 60 peternak, di dapatkan jumlah skor tertinggi mengenai pengetahuan/keterampilan IB tertinggi kabupaten Sidrap dan Bantaeng, dibandingkan 4 kabupaten lainnya. Dengan petugas IB terbanyak di kabupaten Bantaeng dan Bulukumba. Oleh karena itu peranan teknologi IB haruslah diimbangi dengan peningkatan pengetahuan dan keterampilan SDM peternak, melalui peningkatan pelayanan oleh petugas peternakan (PPL, inseminator) dan juga peningkatan hijauan makanan ternak.

Menurut Ibrahim (2001), beberapa masalah yang umumnya terjadi di lapangan menunjukkan bahwa rendahnya pengetahuan dan keterampilan peternak tentang cara beternak yang baik, terjadinya kawin serumpun pada kawanan ternak sapi, masih adanya penyakit menular (brucellosis) pada sapi, serta kurang tersedianya pakan/hijauan makanan ternak yang berkualitas, kesemuanya adalah merupakan faktor-faktor yang menyebabkan rendahnya produksi dan produktifitas ternak sapi.

Mubyarto (1986), menyatakan bahwa tingkat pendidikan peternak akan mempengaruhi pola berpikir, kemampuan belajar, dan taraf intelektual. Dengan pendidikan formal maupun informal maka peternak akan memiliki pengetahuan dan wawasan yang luas sehingga lebih mudah merespon suatu inovasi yang menguntungkan bagi usahanya.

Agrovital | Jurnal Ilmu Pertanian Universitas Al Asyariah
Demikian pula dengan peternak yang pengalaman beternaknya cukup lama akan lebih mudah diberi pengertiannya (Margono dan Asngari 1969).

Persepsi peternak terhadap inseminasi buatan merupakan tanggapan para peternak sapi potong terhadap inseminasi buatan, yang dilihat dari tingkat pengetahuan peternak, minat peternak dan penilaian peternak sapi potong terhadap manfaat insemnisasi buatan sebagai suatu inovasi bagi mereka. Penilaian baik peternak terhadap keuntungan relatif dari inseminasi buatan karena peternak telah melihat hasil ternak IB mempunyai kenaikan berat badan yang cepat. Hal ini sesuai dengan pendapat Ismaya (1999) bahwa dengan menggunakan inseminasi buatan, peternak mendapatkan bibit yang unggul serta memperoleh keturunan yang cepat besar disamping tinggi produksinya (kenaikan berat badan dan produksi susu). Toelihere (1970) juga berpendapat bahwa dengan menggunakan inseminasi buatan dapat mempertinggi breeding efficiency, karena hanya semen yang fertilitasnya tinggi yang diberikan kepada peternak, maka calving interval dapat diperpendek dan jumlah betina yang kawin berulang dapat dikurangi.

Dengan melihat tingkat kelahiran IB yang masih relatif rendah dapat diprediksi bahwa populasi sapi hasil IB di Sulawesi Selatan tidak dapat memberikan kontribusi yang banyak dalam mendukung program pemerintah sejuta ekor sapi di tahun 2013. Menurut Anonim (2009), bahwa walaupun hasilnya sampai saat ini sudah dirasakan oleh masyarakat yang ditandai dengan tingginya harga jual dari ternak hasil IB, namun demikian pelaksanaannya di lapangan belum optimal sehingga hasilnya (tingkat kelahiran) dari tahun ke tahun masih berfluktuasi.

\section{Kajian Pencapaian Program Sejuta Ekor Sapi di Sulawesi Selatan}

Prediksi pertambahan populasi ternak sapi propinsi Sulawesi Selatan dari tahun 2006 sampai dengan tahun 2009 hasil IB dan kawin alam dihitung berdasarkan hasil analisa trend kelahiran yang diperoleh dari 6 sampel kabupaten kemudian dibuatkan skenario prediksi hingga tahun 2013 yang dapat dilihat pada

\section{Gambar 3.}

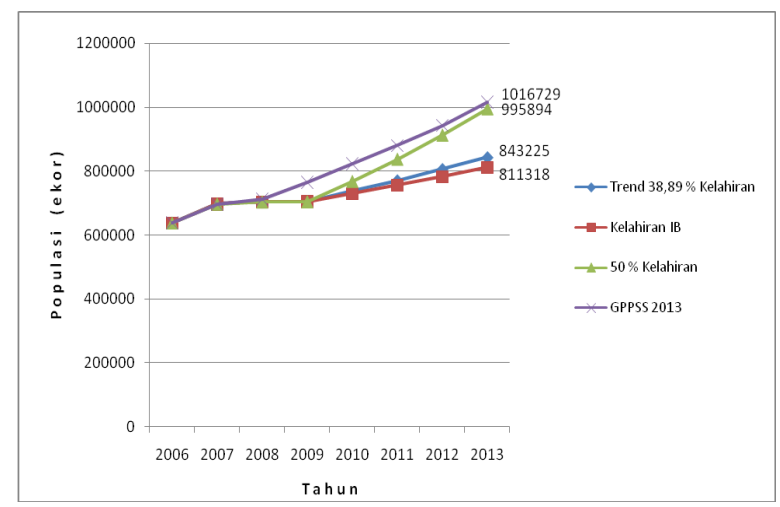

Gambar 3. Grafik Skenario Prediksi Pertambahan Populasi Hingga 2013 
Dari grafik dapat dilihat bahwa trend kelahiran dari tahun 2006 sampai 2009 yaitu 38,89\%. Dengan acuan tersebut didapatkan jumlah populasi total 2013 sebanyak 843.225 ekor dan trend $38,36 \%$ untuk kelahiran IB sebanyak 811.318 ekor. Adapun jika diasumsikan trend kelahiran $50 \%$ berdasarkan tingkat kelahiran di negara lain, maka dengan mengacu pada trend kelahiran tahun 2009, maka didapatkan jumlah populasi akan mencapai 995.894 ekor. Sedangkan prediksi GPPSS 2013 mencapai 1.0167.29 ekor sapi .

Asumsi tersebut diambil berdasarkan pernyataan Trikesowo et al., (1993) bahwa jika dibandingkan dengan sapi asal Australia, Indonesia masih tergolong rendah yakni calf crop-nya dapat mencapai $85 \%$. Hal senada juga di ungkapkan oleh Astuti et al. (1983) bahwa produktivitas ternak potong di Indonesia masih tergolong rendah dibanding dengan produktivitas dari ternak sapi di negara-negara yang telah maju dalam bidang peternakannya.

Berdasarkan grafik Gambar 3. menunjukkan bahwa populasi sapi sejuta ekor belum dapat dicapai di tahun 2013 dengan jumlah trend kelahiran 38,89\% dengan mengacu pada trend 2009, termasuk populasi hasil IB dengan nilai trend $36,38 \%$ yang tidak banyak memberikan kontribusi yang signifikan terhadap target sejuta ekor sapi. Hal tersebut dapat mencapai target dengan tetap meningkatkan jumlah kelahiran sebaiknya lebih dari $50 \%$, dengan tetap mengurangi pemotongan, kematian dan impor khususnya ternak betina produktif, meningkatkan intensifikasi IB.

Berdasarkan penelitian ini dengan mengambil sampel 6 kabupaten didapatkan total persentase kelahiran mencapai $39,8 \%$ dari total akseptor yang terealisasi akhir tahun 2009 sebanyak 14.361 ekor. Sebagaimana yang dinyatakan oleh Toleng (2009), bahwa peningkatan angka kelahiran dapat juga dilakukan dengan meningkatkan jumlah kebuntingan pada ternak betina produktif, baik melalui intensifikasi program inseminasi buatan (IB) maupun kawin alam, untuk mencapai target 1 juta ekor, bahkan lebih, tahun 2013 bukanlah suatu hal yang sulit. Salah satu skenarionya adalah; populasi sapi sekitar 700.000 ekor tahun 2008, jumlah induk fertil/subur sekitar $50 \%$ dari populasi, angka kelahiran sekitar $50 \%$, pemotongan dilakukan hanya pada ternak jantan atau induk yang tidak fertil dan jumlahnya stabil seperti tahun-tahun sebelumnya $(70.000-80.000$ ekor/tahun), angka kematian maksimal sekitar $5 \%$, tidak boleh ada pengeluaran ternak, import daging sekitar 8.000 ton/tahun, konsumsi masyarakat akan daging sapi dibatasi maksimal $2 \mathrm{~kg} / \mathrm{kapita} / \mathrm{tahun}$, maka pada tahun 2013 populasi bisa mencapai lebih dari 1 juta ekor.

Dinas Peternakan Propinsi Sulawesi Selatan dalam program kerjanya mencanangkan pencapaian populasi sejuta ekor sapi pada tahun 2013 untuk 23 kabupaten/kota se-Sulawesi Selatan. Program populasi sejuta ekor sapi di Propinsi Sulawesi Selatan didasarkan atas prediksi umum dengan tingkat pertumbuhan ratarata per tahun minimal $7 \%$ dari total populasi yang ada saat ini (tahun 2009) diprediksi sebanyak 703.965 ekor ternak. Berdasarkan hal tersebut telah dinyatakan oleh Sonjaya (2009), bahwa pada awal tahun 1990-an Sulawesi Selatan pernah mencapai angka populasi 1,2 juta ekor dan menjadi pusat produsen bibit dan sapi yang menyuplai kebutuhan nasional, maka pada saat ini justru memperlihatkan trend yang menyedihkan. Memasuki tahun millenium jumlah populasi sapi hanya mencapai 718.164 ekor, tahun 2001 menjadi 722.452 ekor, dan tahun berikutnya cenderung menurun seperti pada tahun 2006 menjadi 637.128 ekor. Faktor penyebab penurunan diatas telah dibuktikan dengan kajian data tingkat pemotongan tingkat pengeluaran sapi, tingkat pemasukkan dan tingkat kelahiran pada tahun 2005.

Pemerintah Sulawesi Selatan melalui program GPPSS 2013 ini bertujuan mengembalikan kejayaan persapian di Sulawesi Selatan dengan target 1 juta ekor tahun 2013 yang diikuti dengan peningkatan kualitas sapi, peningkatan kualitas sumberdaya dan manajemen pemeliharaan. Dinyatakan oleh Anonim (2009), bahwa pencapaian target tersebut melalui strategi :1)Upaya peningkatan kelahiran dengan intensifikasi IB (IB Mandiri) dan kawin alam dengan pejantan unggul, diikuti dengan 2)Pengendalian pemotongan dengan pencegahan pemotongan betina produktif, peningkatan kualitas (ukuran) ternak, pengandalian kematian dan pengendalian pengeluaran ternak, dan 3)Program Pendukung yang meliputi upaya pengembangan SDM, peningkatan sarana pendukung, penguatan modal, penguatan kelembagaan dan monitoring.

Mencermati wacana tersebut maka evaluasi dalam upaya peningkatan populasi ternak sapi di propinsi Sulawesi Selatan baik melalui intensifikasi IB dan kawin alam dalam beberapa tahun terakhir dapat dilakukan dengan pengambilan sampel rata-rata trend kelahiran dari tahun 2006 sampai dengan tahun 2009 di enam kabupaten dan memproyeksikan pertambahan populasi hingga tahun 2013.

Dinyatakan oleh Anonim (2009), bahwa target kelahiran IB dan Kawin Alam dari Tahun 2008 - 2013 di Sulawesi Selatan dihitung berdasarkan target akseptor IB $25 \%$ dari induk produktif pada 9 kabupaten wilayah IB utama dan $10 \%$ di kabupaten lain, dan target 55\% akseptor kawin alam intensif pada 21 kabupaten. Berdasarkan asumsi tersebut akan diperoleh kelahiran sebesar $41 \%$ dari induk produktif. Pemotongan, kematian dan pengeluaran ternak (PMK) diasumsikan sebesar $11.7 \%$ masing-masing pemotongan $9 \%$, kematian $2.5 \%$ dan pengeluaran $0.2 \%$. Semua asumsi tersebut dapat dicapai jika GPPSS dilaksanakan.

\section{Kesimpulan}

1. Populasi hasil IB di setiap kabupaten cenderung mengalami peningkatan setiap tahunnya meskipun pertambahannya relatif sedikit sehingga dapat diprediksi bahwa jumlah kelahiran hasil IB tidak dapat mendukung program pemerintah GPPSS 2013.

2. Target pemerintah sejuta ekor sapi tidak dapat tercapai jika trend kelahiran tetap pada nilai $38,8 \%$ sampai tahun 2013. 
Saran

Pencapaian program sejuta ekor sapi dapat tercapai apabila tingkat trend kelahiran rata-rata diatas $50 \%$ dengan jumlah induk $40 \%$, dengan meningkatkan jumlah kelahiran, mengurangi pemotongan, kematian dan impor, khususnya ternak betina produktif, meningkatkan manajemen pemeliharaan serta pengetahuan dan keterampilan bagi peternak/petugas IB serta meningkatkan intensifikasi IB.

\section{Daftar Pustaka}

Anonim, 2009. Business Plan. Gerakan Peningkatan Populasi Sapi Sejuta ekor tahun 2013. http://disnaksulsel. info (diakses tanggal 15 Januari 2010)

Ibrahim, S. 2001. Strategi Peningkatan Kualitas Pelayanan di Lingkungan Penyuluhan Peternakan, Dinas Peternakan dan Perikanan Kabupaten Sidenreng Rappang.

Margono, Slamet dan P.S. Asngari, 1969. Penyuluhan Peternakan. Direktorat Jenderal Peternakan Departemen Pertanian. Jakarta.

Mubyarto, 1986. Pengantar Ekonomi Pertanian. LP3ES. Jakarta.

Putu, I.G., Dewyanto, P. Sitepu, T.D. Soedjana, 1997. Ketersediaan dan Kebutuhan Teknologi
Produksi Sapi Potong. Proceeding Seminar Nasional Peternakan dan Veteriner, Bogor, 7-8 Januari 1997 hal. 50-63.

Sonjaya, H. 2009. Mengkaji Program Pencapaian Populasi Sejuta ekor sapi Tahun 2013 di Provinsi Sulawesi Selatan. $\quad$ http://saintisakademik.blogspot.com. (diakses 5 Januari 2010)

Subandi dan Zubachtirodin. 2004. Prospek Pertanaman Jagung dalam Produksi Biomas Hijauan Pakan. Prosiding Seminar Nasional. Pemberdayaan Petani Miskin di Lahan Marginal Melalui Teknologi Tepat Guna. BPTP NTB. Puslitbangsosek. Badan Litbang Pertanian.

Sugeng, Y. B. 2002. Sapi Potong. Penebar Swadaya, Jakarta.

Toelihere, M.R. 1985. Inseminasi Buatan pada Ternak. Edisi ke-2. Angkasa, Bandung. 292 hal.

Toleng, A.L, 2009. Optimisme Terhadap Populasi Sejuta Ekor Sapi. http://www.latieftoleng.blogspot.com (diakses 7 Maret 2010)

Trikesowo, N., Sumadi dan Suyadi. 1993. Kebijakan Riset di Bidang Pengembangan dan Perbaikan Mutu sapi Potong dengan teknik Ladang Ternak dan feedlot. Forum komunikasi Hasil Penelitian Bidang Peternakan, Yogyakarta. 